\title{
Weber and Judicial Legitimacy: A Critical Analysis of the U.S. Supreme Court Immigration Cases Nielsen v. Preap (2019) and Barton v. Barr (2020)
} Journal of Criminal Justice and Law: Official
Journal of the Law and Public Policy Section
of the Academy of Criminal Justice Sciences
Volume 4, Issue 1, pp. 1-21 (2020)

\section{Frances P. Bernat', Craig Curtis", and Rebecca Davalos'}

\begin{abstract}
This paper analyzes the legitimacy of two U.S. Supreme Court decisions, Nielsen v. Preap and Barton v. Barr, against the principles expressed in Max Weber's theories regarding rational legal order and judicial legitimacy. The legitimacy of our judiciary depends on the public perception that it is a politically neutral, non-partisan arbiter of the rule of law in our society. When the Court is perceived as serving partisan interests, or promoting arbitrary action by the executive branch, its legitimacy is threatened. After careful exploration of the value of an impartial and politically neutral judiciary as seen through the lens of Weber's theories, the inescapable conclusion is that both the Nielsen v. Preap and Barton v. Barr rulings are neither just nor fair, and are harmful to the legitimacy of the judiciary.
\end{abstract}

During the 2018 term of the United States Supreme Court, the Justices waded into the politically sensitive issue of immigration and deportation of permanent legal residents in the case of Nielsen v. Preap (2019). In the following 2019 term, the high court analyzed another challenge to the deportation of a permanent legal resident in Barton v. Barr (2020). The Department of Homeland Security under the mandated policies of the Trump Administration sought to remove resident aliens from the interior of the United States if they committed removable offenses. In $2019,86 \%$ of persons arrested by ICE had criminal convictions or pending charges, and $85 \%$ of persons removed from the United States to their home nations had served time while in ICE custody (U.S. Immigration and Customs Enforcement, 2019).

The immigrants in Nielson (2019) had been convicted of crimes, served their criminal sentences, and had been released. However, in subsequent years, the government claimed a right under federal statutory law to incarcerate the immigrants and denied them a bond hearing

\footnotetext{
'Texas A \& M International University, Laredo, TX, USA.

"Bradley University, Peoria, IL, USA.

Corresponding Author:

Frances P. Bernat, Texas A \& M International University, 5201 University Boulevard, Laredo, TX 78041.

Email: frances.bernat@tamiu.edu
}

The authors wish to express their appreciation to the blind reviewers of the original manuscript for their comments, which were helpful during preparation of the final version of the manuscript. 
pending their deportation hearings. The bond hearing denial effectively kept them incarcerated, indefinitely, while their deportation hearing slowly moved forward. In Barton (2020), a permanent legal resident came to the United States in 1989 on a visitor visa. He then became a lawful permanent resident in 1992. In 2008, Barton was convicted of drug offenses and the Department of Homeland Security sought to deport him on the theory that his earlier crimes made him inadmissible, in effect seeking to retroactively retract his legal residency status.

In the present essay, we analyze judicial legitimacy by focusing on the legal language employed by the Court majority in Nielsen (2019) and Barton (2020). Bartels and Johnson (2013) argue that the legitimacy of the Court is important because unlike the legitimacy of the executive and legislative branches, the judiciary is not directly accountable to the public since the Justices are not elected and serve life terms. Rather than focus on the public's political ideological leanings as Bartels and Johnson (2013) did in their judicial legitimacy research study, we consult the work of German sociologist Max Weber. Weber wrote extensively on the nature of legitimacy of government (Weber, 1946; 1958) and the value of an independent judiciary (Weber, 1966; 1983). His ideas were influential in the development of our national conception of legitimacy in the twentieth century (Schaff, 2014). He envisioned an ideal nation that used rules and laws to ensure order, consistency, predictability, and fairness in the outcome of legal conflicts. He viewed, therefore, the United States as having an advanced rational legal order which was unparalleled in the world. According to Chen (1999, p. 100), "Weber's concept of formal rationality as applied to legal systems suggests that in modern Western legal systems, the law consists of a comprehensive system of coherent general rules and principles that can be applied in a rational, consistent and predictable manner, through a uniquely legal mode of reasoning, by an independent judiciary with the aid of a specialized legal profession." The advancement of a formal legal system over other forms of government, in Weber's view, is that abstract principles can be used to apply law uniformly and with reason to achieve individualized case results while upholding the overall governmental aims to promote the public welfare. As Sahni $(2009$, p. 213) points out, Weber articulated a unique position for the judiciary, one in which the judiciary shoulders the burden of advancing positive law "on the basis of ethics, equity, or expediency" while it decides the individual outcome of a case.

The Nielsen (2019) and Barton (2020) decisions provide an opportunity to evaluate the legitimacy of the Court's decisions against Weber's views of a rational legal system. Such an examination enables us to consider the Court's holdings when it addresses immigration and justice issues during a politically charged time period. The American legal system is touted as one that maintains the rule of law while sustaining the ideals of equality and natural rights. The separation of powers among its branches of government is believed to be a stronghold for freedom as it preempts any one branch dominating another. For the judiciary, in particular, the American legal system is praised for its adherence to political neutrality and the dispensation of justice. The American judiciary can lose respect, legitimacy, if it is deemed to be a political entity whose function is to interpret statutory law in a formalistic, mechanical style rather than analyze law in the context of policy formulation and constitutional rights. In recent years, the Court has been shying away from a role of assessing statutory law against constitutional values. As Lasser (2009) points out, despite the rhetoric that the U.S. Supreme Court provides policy formulations, the Court also provides analyses which engender "anti-policy rhetoric" that flows from its legal formalism roots rather than the more modern legal realism tradition which promotes 
contemporary socio-economic values. To the extent that the Court's decisions stem from a political or formulistic perspective, rather than from legal realism, the Court opens itself to criticism on the legitimacy of the particular legal holding and on the role of the judiciary in the United States.

Legitimacy of the judiciary in the United States is sustained when minimal reliance is placed on archaic customary norms while the Court underscores the value of abstract legal principles as a framework in its decision-making. American traditional notions of fairness, for example, provide that all individuals in our legal system have the right to due process and equal protection of law. These rights are not absolute. Specific strictures of constitutional magnitude must be adhered to in order to ensure procedural and substantive fairness for individuals caught within the web of our civil and criminal justice system. If the judiciary is viewed as espousing the ideology of any one political party, or of the President, then judicial legitimacy fails to provide the constant adherence to abstract law. For Weber, while politicians can be flexible and change their views to gain the public's confidence and support, the formal legal system needs to maintain impartiality to obtain its legitimacy and accountability to the populace. A lack of accountability is unacceptable in a rational legal order particularly during divisive times because in such times the public may scrutinize the legal system's authority and reject the judiciary's claims to independent authority and legitimacy. For several decades, the Supreme Court has been "the umpire of the democratic process" (Ackerman, 2002, p. 142). By using Weber's framework, we will analyze whether the two Supreme Court immigration cases sustain or threaten judicial legitimacy in a formal legal system aimed at the dispensation of fairness and justice.

The paper that follows will consist of three main parts. First, the facts and holding in Nielsen (2019) and Barton (2020) will be detailed and placed in the relevant political environment. Second, a summary of the relevant concepts of Max Weber will be used to identify the components of a model judiciary that is both consistent with his idea of formal rational law and well suited to the preservation of legal rational order in American society. Third, the essay will answer two questions. The first question is whether the United States Supreme Court's decision to deny substantive review of the claims of Preap and Barton is consistent with Weber's theory of formal rational law. The second question is whether the majority rulings promote the legitimacy of the Supreme Court, and the judicial system as a whole. Both questions are answered in the negative.

\section{THE ISSUE, FACTS, AND HOLDING IN NIELSEN V. PREAP (2019)}

At issue in Nielsen (2019) was whether Title 8 U.S.C. § 1226(c)(1)(A)-(D) requires the Secretary of Homeland Security to immediately arrest and detain certain enumerated "criminal aliens" upon their release from criminal custody. On its face, Title 8 U.S.C. $\S 1226(c)(1)(A)-(D)$ requires mandatory detention of the enumerated criminal aliens upon their release from criminal custody and throughout the duration of the pendency of their immigration case, but that is not what happened to these plaintiffs.

Mony Preap, the lead plaintiff in Nielsen (2019), came to the United States in 1981 as an infant. His family were refugees fleeing the Khmer Rouge in Cambodia. He spent time in jail in California for two convictions for possession of marijuana in 2006, both misdemeanors. These offenses are both predicate offenses under Title 8 U.S.C $\$ 1226(c)(1)(A)-(D)$ of the United States Code that would enable him to be classified as a criminal alien subject to deportation. He was not detained in 2006 upon release from custody for those offenses. In 2013, he was arrested for simple battery which 
is not a Title 8 U.S.C. $\$ 1226$ (c) predicate offense. Upon his release from jail in 2013, he was seized by immigration officials and held without bond pending a determination of whether he was deportable. The other plaintiffs were similarly situated. All had been convicted of predicate offenses that could cause them to be deportable criminal aliens under federal law, but they were not seized or deported immediately upon release from custody for those predicate crimes. Among the plaintiffs, the longest interval between release from custody for a predicate offense and being subjected to detention without bond was eleven years. The 9th Circuit held that the detainees had a right to have a bond hearing and could only have been detained if "immediately held" when they finished their predicate crime sentences. With regard to Preap, he should have been held when released in 2006 and not in 2013 (Preap v. Johnson, 2016).

The Supreme Court's 5-4 majority opinion by Justice Alito did not focus its attention on an analysis of the constitutional issues raised by the immigrants' detentions without bond. The Court instead presented a lengthy opinion focused mainly on grammar and syntax in the statute at issue and found that the statutory law did not require the immediate arrest and detention upon release of criminal aliens from criminal custody (Nielsen v. Preap, 139 S. Ct. 954, at 964, 2019):

Paragraph (1) provides that the Secretary "shall take" into custody any "alien" having certain characteristics and that the Secretary must do this "when the alien is released" from criminal custody. The critical parts of the provision consist of a verb ("shall take"), an adverbial clause ("when ... released"), a noun ("alien"), and a series of adjectival clauses ("who . . . is inadmissible," "who . . . is deportable," etc.). As an initial matter, no one can deny that the adjectival clauses modify (and in that sense "describ[e]") the noun "alien" or that the adverbial clause "when ... released" modifies the verb "shall take." And since an adverb cannot modify a noun, the "when released" clause cannot modify "alien." Again, what modifies in that sense "describe[s]") the noun "alien" are the adjectival clauses that appear in subparagraphs (A)-(D).

The Court thus held that the potentially deportable immigrants could be detained at any time after their release from a deportable criminal sentence and held indefinitely without the ability to have a bond release hearing. In doing so, the Court opened itself up to attack on several fronts. One front is whether the judiciary is aligning itself with the political ideology of President Trump and the view that immigrants are criminals who should be summarily deported. Another front is that the Court is not adjudicating the facts of the case by applying abstract adherence to constitutional law, instead relying on strict interpretation of the language in the statute. Finally, the dissent pointed out the legal flaws in the majority's analysis by looking at the larger political and social issues on immigration and governmental legitimacy. Justice Breyer found the majority opinion's outcome to be problematic, both socially and legally (Nielsen v. Preap, Breyer dissent, $139 \mathrm{~S}$. Ct., 954, at 978, 2019):

These aliens may then be detained for months, sometimes years, without the possibility of release; they may have been convicted of only minor crimes-for example, minor drug offenses, or crimes of "moral turpitude" such as illegally downloading music or possessing stolen bus transfers; and they sometimes may 
be innocent spouses or children of a suspect person. Moreover, for a high percentage of them, it will turn out after months of custody that they will not be removed from the country because they are eligible by statute to receive a form of relief from removal such as cancellation of removal. These are not mere hypotheticals.

He concluded by imputing American legal traditions to Congressional intent (Nielsen v. Preap, Breyer dissent, 139 S. Ct. 954, at 985, 2019):

I would have thought that Congress meant to adhere to these values and did not intend to allow the Government to apprehend persons years after their release from prison and hold them indefinitely without a bail hearing.

\section{THE ISSUE, FACTS, AND HOLDING IN BARTON V. BARR (2020)}

At issue in Barton (2020) was whether Title 8 U.S.C. $\S \S 1229 b(a),(d)(1)(B)$ would enable a lawful permanent resident who is undergoing removal proceedings from the United States to have the deportation cancelled under the provisions of Title 8 U.S.C. $\$ 1182(a)(2)$. Andre Martello Barton came to the United States from Jamaica in May, 1989, as a B-2 visitor and received a green card about three years later. In January, 1996, he was charged with three counts of aggravated assault, one count of first- degree criminal damage to property and one count of possession of a firearm during the commission of a felony. He was convicted of these offenses in July, 1996. However, the government did not initiate removal proceedings at that time. In 2007, Barton was arrested for three drug offenses in the State of Georgia and subsequently convicted the following year. It was after those later convictions that the government acted to deport Barton. Because the 2008 convictions occurred long after his continual residence in the United States, his deportation proceedings had complicated time frames which would make it impossible to pursue removal proceedings. The government sought to retroactively declare him "inadmissible" for entry into the United States. Barton petitioned the immigration court to cancel his removal because he was a lawful permanent resident who had long been admitted and continuously living in the United States. The government argued that he did not meet the seven years of continuous residency because of the stop-time rule provided for in the Immigration and Naturalization Act $\S 240 A(d)(1)(B)$. The 11th Circuit agreed with the government's position and held that the stoptime rule plainly applied to the removal of permanent legal aliens even if they were not seeking admission into the United States because they were already in the country at the time of their removal proceeding (Barton v. U.S. Attorney General, 2018).

The Supreme Court's 5-4 majority opinion by Justice Kavanaugh focused on the "inadmissibility" of Barton as an alien seeking entry into the United States, not his "deportability" as a permanent legal resident. Justice Kavanaugh noted that the cancellation of removal statute is akin to a recidivism law in the criminal justice system (Barton v. Barr, 140 S. Ct. 1442, at 1445-1446, 2020).

Despite the appearance of a simple statutory interpretation by the majority, the case raises serious constitutional concerns for persons who have been admitted into the country and have thereafter been conferred with permanent legal residency status. The Court declined to address 
these concerns, basing its decision on a close parsing of certain portions of the statute concerning the stop-time rule. The Court was succinct, and terse, in its reply to Barton's legal argument regarding inadmissibility. The Court stated: "as relevant here, $\$ 1182(a)(2)$ flatly says that a noncitizen such as Barton who commits a crime involving moral turpitude and is convicted of that offense 'is inadmissible.' §1182(a)(2)(A)(i). Full stop." (Barton v. Barr, 140 S. Ct. 1442, at 1451-1452, 2020).

As with Justice Breyer's dissent in Nielsen (2019), Justice Sotomayor's dissent called into question the majority's paradoxical analysis:

The majority errs by conflating these two terms. It concludes that the term "inadmissible," for the purposes of the stop-time rule, refers to a status that a noncitizen could acquire even if he or she is not seeking admission. Under this logic, petitioner Andre Barton is inadmissible yet, at the same time, lawfully admitted. Neither the express language of the statute nor any interpretative canons support this paradox; Barton cannot and should not be considered inadmissible for purposes of the stop-time rule because he has already been admitted to the country (Barton v. Barr, Sotomayor dissent, 140 S. Ct. 1442, at 1455, 2020).

Barton's arrest and convictions, which gave rise to the deportation process, were 10 years after his earlier arrests, but these later arrests and convictions were not the basis for deportation. The offenses from 1996 were used as the basis for the deportation proceedings. The dissent was troubled that the state used the inadmissibility aspects of the law to deport him because Barton would have been able to use the stop-time rule if he was "removable" but not if he was "inadmissible."

Boiled down to its essence, the majority used a convoluted interpretation of the statute retroactively to undo the legal residency status long since granted to Barton. They did not focus on Barton as an individual, or on his rights. Sotomayor's dissent harshly points this out:

... (T)he Court's interpretation is at odds with the express words of the statute, with the statute's overall structure, and with pertinent canons of statutory construction. It is also at odds with common sense. (Barton v. Barr, Sotomayor dissent, 140 S. Ct. 1442, at 1462, 2020).

\section{IMMIGRATION AND THE TRUMP ADMINISTRATION: WHY THESE DECISIONS APPEAR TO BE POLITICAL}

The United States in 2019 and 2020 found itself deeply divided over some significant issues regarding President Trump's actions and policy declarations. At the center of these concerns was the potential of the President's removal from office (Keneally, 2020) and his ability to avoid Congressional oversight. The House impeached the President on two articles of impeachment at the end of 2019, but the Senate declined to bring any witnesses and quickly voted in 2020 to acquit the President on both articles. The votes in both houses of Congress were primarily along party lines reflecting the hyper-partisanship of the times. 
The political divisions did not abate with the acquittal of the President in the Senate. Three cases challenging the ability of the President to withhold his financial records were reviewed by the Court in the 2019 term. ${ }^{1}$ Unlike other Presidents who publicly shared their tax returns when running for election, President Trump refused to do so. He refused to respond to state and Congressional subpoenas to turn over various documents pertaining to his business dealings and tax returns. The Court handed down decisions on these cases in Trump v. Vance (2020) and Trump v. Mazars (2020). The decisions manifest a win and loss for the President. The Court held that the President cannot to refuse to abide by a state subpoena merely because it is a "distraction" for his office (Trump v. Vance, 2020), but the courts can consider whether a Congressional subpoena conflicts with separation of powers among the branches of government (Trump v. Mazars, 2020). These cases were then remanded to the lower courts to continue with the litigation in light of the Court's rulings.

The Trump Administration's stance on immigration in 2019 was related to his campaign promises to change immigration law and policy. Prior to the Nielsen (2019) decision, the Court ruled on another significant legal challenge to his immigration policy in Trump v. Hawaii (2018). That case cast some doubt on the willingness of the Court to check the President's public stance to exert political control over Congress (Wehle, 2020) and the judiciary (Stevens, 2020). The Court majority held that the President has authority under the Immigration Nationalization Act to issue emergency orders to protect the nation. Despite President Trump's statements that Muslims from certain nations present a terrorist danger to the United States, the majority found the President's proclamations and the executive order to be within his statutory and constitutional powers. Justice Sotomayor's dissent in Trump v. Hawaii (2018) accused the majority of dancing around the issue of whether the President can be held to account for his own words: "a reasonable observer would conclude that the Proclamation was driven primarily by anti-Muslim animus, rather than by the Government's asserted national-security justifications" (Trump v. Hawaii, Sotomayor dissent, 138 S. Ct. 2392, at 2438, 2018).

Any policy decision by the President in 2019 concerning immigration was bound to add to the political conflict the nation was facing. The Court couched its majority decisions in both Nielsen (2019) and Barton (2020) as narrow matters of statutory interpretation. The characterization that the decision is narrow is exactly the form of legal argument and decision making a court will do when they know that the decision is controversial. A narrow ruling portends of neutrality so as to hide judicial partiality (Pedrioli, 2016). President Trump's Supreme Court nominees Justices Gorsuch and Kavanaugh were extensively questioned during their confirmation hearings about their views of the unitary executive and their willingness to rule against the President if, and when, litigation came to the Court concerning the limits of his authority (Flegenheimer et al., 2017; Liptak et al., 2018). Both Justices are regarded as favoring an expansive view of executive power (Totenberg, 2018). Whether the President will ultimately avoid Congressional oversight in the performance of his duties is an open question at the time of writing. There is ample reason, consequently, for observers of the Court to be concerned about its political independence and its legitimacy.

\footnotetext{
${ }^{1}$ The cases are Trump v. Vance (2020), Trump v. Mazars (2020), and Trump v. Deutshe Bank (19-760), which was consolidated on appeal with Trump v. Mazars (2020).
} 


\section{WEBER AND A FORMAL, RATIONAL LEGAL SYSTEM}

In assessing challenges to the legitimacy of the judiciary, it is useful to consult the German sociologist Max Weber. He traveled in the United States in the early part of the Twentieth Century and was strongly affected by what he saw (Schaff, 2011). His ideas were well known in the United States during the early and middle parts of the Twentieth Century and his ideas played an important role in the development of our twentieth century notions of the legitimacy of our government and social structures (Schaff, 2014, p. 13-14). Weber wrote extensively on the nature of the legitimacy of government as a stratification theorist (Weber, 1946; 1958). Unlike other such theorists who often warned of the inherent flaws in a stratified society, he focused much of his attention on the issue of how a stratified society could sustain itself by virtue of being considered legitimate by those who lived in it. For Weber, what made a stratified society viable was a commonly understood and accepted set of legitimizing beliefs. Weber suggested three possible bases for the legitimacy of a stratified society. These are the Traditional, the Charismatic, and the Legal Rational (Weber, 1958).

The traditional justification is based on a generally accepted justification for stratification, such as religion. Examples would include any of a number of ancient kingdoms based on the idea that the ruler was, him or herself, divine. Charismatic regimes are based on the unique talents of a leader, such as Alexander the Great, which have a leader's followers owing allegiance to the ruler due to the leader's personal traits. Legal rational justifications for the maintenance of order depend on a shared set of legitimizing beliefs. Those legitimizing beliefs are expressed in the dominant normative political philosophy that is the basis for the legal and political order in the state. The old Soviet Union was based on the Stalinist and Leninist versions of Marxism. The United States is based on a set of ideas that inspired the Founders, including the social contract, natural law, the rule of law, Enlightenment Liberalism, and capitalism. In a modern society, Weber's ideas mean that a set of legitimizing beliefs is essential for the functioning of a democracy (Lipset, 1959). To the extent that President Trump exhibits charismatic leader attributes, it might be important to consider how non-followers of the President might contribute to his success. Joosse $(2018$, p. 930), for example, argues that during President Trump's 2016 campaign, his "racist, sexist, and xenophobic statements with a puerile masculinity affected a combative style that simultaneously outraged and enthralled audiences...." As a consequence, Trump was set apart from his GOP rivals and was able to exhibit a form of charisma that played off of "unworthy challengers" who were outside of his base (Joosse, 2018). That the Supreme Court might render decisions on formulistic pronouncements, as they did in Nielsen (2019) and Barton (2020), rather than abstract law is disconcerting. It could mean the loss of judicial legitimacy. With Justices who espouse strict construction philosophy, the Justices may be deferring their role as an interpreter of what the law is vis-à-vis the power of judicial review to the other branches, and be swayed by the rhetoric of the President.

For Max Weber, law was a system of rules to ensure order (Farmer, 2013; Sabuktay, 2009). In particular, Weber envisioned an ideal bureaucracy with a system of written rules enforced by qualified and trained individuals organized in a hierarchy for proper, consistent, and systematic implementation and application of uniform and fair rules (Lane, 2017; Sabuktay, 2009). Additionally, Weber provided that legal-rational authority of the type with formal procedures lends legitimacy to the law under the rule of law. In tandem with his ideal bureaucracy (Weber, 1946), Weber identified four types of law: (1) substantive irrational law, characterized by reliance 
on emotional, personal, or political bias; (2) formal irrational law, characterized by reliance on the supernatural; (3) substantive rational law, characterized by reliance on non-legal sources, such as religious texts; and (4) formal rational law, characterized by "the equal application of logical and consistent rules that are independent from religious and other normative criteria" (Farmer, 2013, p. 148). Weber sought to provide a justification for the maintenance of order in a society, and that maintenance of order in a democracy is highly dependent on willing compliance with the law by the citizens. The willing compliance come from near universal acceptance of basic principles of our limited government. As John Adams famously said, "We are a nation of laws, not of men." That rules out both substantive and formal irrational law since neither form of law is consistent with the rule of law. Weber's idea of substantive rational law may seem, at first glance, consistent with the natural law origins of some aspects of our system since it is based on biblical authority, but it is also inconsistent with the Establishment Clause of the First Amendment. That leaves us only with formal rational law, which involves formal procedures that should lead to consistent results (Farmer, 2013; Novak, 2013). Under formal rational law, people should obey the law because the "rules" authorize them to follow the law (see Marquez, 2016, for his critique of legitimacy under Weber's formulation).

The idea that the rule of law is an essential part of the legitimizing beliefs of our society is bolstered by Weber's (1983, p. 28) work, “[M]odern rational capitalism needs, not only the technical means of production, but also a calculable legal system and an administration based on formal rules." Calculable means that citizens can reliably predict what the rules are before beginning a legal case, that reasonable predictions can be made concerning the probability of success of a lawsuit by a lawyer providing advice to a client, and that the jurisprudence that emerges from our system of stare decisis represents a coherent and consistent system of law. This kind of predictability, coupled with a system where the rules are generally regarded as legitimate and where knowledgeable commentators can provide plausible explanations for why the rules are the way they are results in a highly legitimate system.

\section{JUDICIAL LEGITIMACY FLOWS FROM FORMAL LEGAL RATIONALITY}

In assessing challenges to the legitimacy of the judiciary, it is useful to consult Weber's analysis on a formal legal system and the value of an independent judiciary (Weber, 1966; 1983). Weber envisioned a nation of rules and laws to ensure order, consistency, predictability, and fairness in the outcome of legal conflicts. In line with his vision, American traditional notions of fairness and due process provide that United States citizens and most individuals involved with litigation in our legal system have the right to fair notice and to due process of law. While these rights are not absolute, there are specific strictures of constitutional magnitude that must be adhered to in order to ensure procedural fairness to individuals caught up in the web of our civil and criminal justice system.

In praising the American judicial system, Weber (1946, p. 201) wrote, "The superior qualification and integrity of federal judges, appointed by the President, as against elected judges in the United States is well known ...." Integrity means that these judges are following the norms of judicial restraint, impartiality, and devotion to the rule of law that is taught in law schools all across the country. It also means that these judges do not allow personal political preference to influence their rulings. This idea is strongly embedded in our legal system because we want to 
believe that justice is blind and that everyone is equal before the law (Segal \& Spaeth, 2002). It is part of the nation's founding philosophy that a rational legal system is superior to ones based on the caprice of a ruler. Even the justices themselves are quick to criticize their brethren if they think political ideology is driving a decision. ${ }^{2}$

Weber $(1968$, p. 87) argued that formal rational law is beneficial to both those possessed of economic power and to those who want to reform the system to change that distribution of power:

It is precisely this abstract character which constitutes the decisive merit of formal justice to those who wield the economic power at any given time and who are therefore interested in its unhampered operation, and also to those who on ideological grounds attempt to break down authoritarian control or to restrain irrational mass emotions for the purpose of opening up individual opportunities and liberating capacities.

The operation of formal rational law contributes to widespread acceptance of the legal and economic order by those with power, and those without, because it preserves the ability of both to have meaningful input into the political system. To the extent that a decision of the Supreme Court seems more consistent with substantive irrational law, the less legitimacy it can command. A formal rational legal system should possess the following characteristics: 1) a judiciary that makes decisions in an ideologically neutral process; 2 ) a judiciary that is overtly non-partisan; and, 3) a judiciary that renders decisions in a transparent and predictable way, bound by the rule of law, including the principles of judicial restraint.

Evidence of ideological neutrality can be found in a number of ways. There are numerous examples of agreement between Justices appointed by Democrats and Justices appointed by Republicans. Cases like United States v. Jones (2012) and Riley v. California (2014) are examples of near unanimity on the Court despite the issues being of a nature (i.e., criminal procedure) that historically pits conservatives and liberals against one another. Adherence to the norms of practice on the Court, even when the behavior may go against the grain of policy preferences of an individual Justice can be seen in Justice Samuel Alito's refusal to grant a stay in the case of League of Women Voters of Pennsylvania et al., v. Commonwealth of Pennsylvania et al. (2018), and the granting of a stay in Sierra Club v. Trump (2019) by Justice Elena Kagan.

The perception that the Supreme Court is non-partisan is important. Public opinion polls make it clear that public approval of the Court is linked to the perception that it is above partisan politics (Golde, 2019). The Justices are supposed to make every attempt to remain above the political fray. The Justices do sometimes fall short in this endeavor, but the importance of this political independence to the Justices themselves is illustrated by Chief Justice Roberts' recent behavior. His response to President Trump's criticism of a federal judge as an "Obama Judge" was clear and sharp (Liptak, 2018, n.p.):

We do not have Obama judges or Trump judges, Bush judges or Clinton judges. What we have is an extraordinary group of dedicated judges doing their level

2 See, e.g., Justice Roberts' dissent from the ruling in Obergefell v. Hodges (576 U. S. 644, at 686-688, 2015), and Justice Thomas' dissent from the ruling in Department of Homeland Security v. the University of California (140 S. Ct. 1891, at 1919, 2020). 
best to do equal right to those appearing before them. That independent judiciary is something we should all be thankful for.

The value of a politically independent judiciary was further emphasized in Chief Justice Roberts' year-end report on the state of the federal judiciary (Roberts, 2019).

Lastly, the legitimacy of the judiciary is firmly bound in a commitment to the rule of law. This commitment to the rule of law creates both predictability and transparency. All of the Justices in recent times have voiced an explicit commitment to the rule of law and respect for precedent in their confirmation hearings. Senator Susan Collins' vote in favor of Justice Kavanaugh was conditioned on him convincing her that he would respect Roe v. Wade (1973) as a precedent (Collins, 2018). In dissents, the Justices often criticize each other for reliance on factors external to the precise legal issue presented to the Court. ${ }^{3}$ To be clear, it is the abstract principles of the nation's origins which give life to the law. It is the protection of these principles which are the fruit of judicial decision making when interpretation of a statutory law is challenged.

\section{NIELSEN (2019) AND BARTON'S (2020) HOLDINGS ARE UNJUST UNDER MAX WEBER'S RATIONAL LEGAL THEORY}

One can plausibly argue that the rulings in Nielsen (2019) and Barton (2020) are based on extra-legal, political factors; what Weber might have called "substantive irrational law." Farmer $(2013$, p. 148) characterized substantive irrational law as "decided, not by general rules, but by emotional, personal, ethical or political bias and a lack of procedural uniformity." Instead of creating a universally applicable rule that guides prosecutorial discretion in deciding whether to deport a person legally classifiable as a criminal alien, the majority in Nielsen (2019) and Barton (2020) devoted significant space to detailed parsing of the statute itself. Instead of focusing on any substantive constitutional rights that the plaintiffs have, the majority opinions denied any opportunity for the detainees to offer evidence that they are not inherently dangerous. The Constitution forbids bills of attainder for just this reason. By relying on a strained interpretation of the statute, the Court opened itself up to charges that it was responding to the current antiimmigrant political bias of the Executive as opposed to attempting to apply the nation's abstract principles of just law to the procedural criteria in the statute.

The Court refused to "bestow upon the defendant a windfall" and "visit upon the Government and the citizens a severe penalty by mandating release of possibly dangerous defendants every time some deviation from the [statutory] strictures...occur[red]" (Nielsen v. Preap, 139 S. Ct. 954, at 967, 2019, quoting Montalvo-Murillo, 495 U.S. 711, at 720, 1990). Similarly, the Court in Barton compared the plaintiff to a repeat offender in a criminal trial whose past crimes are used to determine his length of sentence (Barton v. Barr, 140 S. Ct. 1442, at 1449, 2020). In both cases, a person who has resided in the United States for a lengthy period of time was to be sent "back" to a place that they would hardly recognize without a full hearing on the issue of whether they were actually a danger to our society.

\footnotetext{
${ }^{3}$ See, Justice Thomas's dissent in Flowers v. Mississippi (139 S. Ct. 2228, at 2254, 2019), Justice Alito's dissent in Fisher v. University of Texas (136 S. Ct. 2198, at 2242, 2016) and Justice Thomas's dissent in Department of Homeland Security v. Regents of the University of California (140 S. Ct. 1891, at 1919, 2020).
} 
The majority opinions in both cases were pieced together by slim margins in 5-4 votes. Five Justices, all appointed by Republican Presidents, outvoted four Justices, all appointed by Democratic Presidents. The majority's refusal to address the constitutional issues raised by the facts in these cases supports a criticism that the Court was behaving in a partisan fashion, especially when considered along with its other recent immigration decision in Trump v. Hawaii (2018). The dissenting opinions in Nielsen (2019) and Barton (2020) focused on the injustice created by the majority's opinion. The four dissenting Justices (Breyer, Ginsburg, Sotomayor, and Kagan) wrote scathing dissents arguing that the majority interpreted the statutes in question incorrectly and that the clear constitutional problems of the statute should have been addressed. In both cases, the litigants faced deportation but had lived for substantial periods of time in the U.S. without legal problems. The dissenting opinions wanted the Court to consider issues of fairness, due process of law, and the equal protection rights and liberties of the potentially deportable immigrant class. Given the strong national and partisan divide on immigration issues and the clear partisan divide among the Justices, there is ample fuel for the argument that the Court is acting in a partisan, politically motivated fashion.

The individuals who were identified and subject to the removal procedures in these two cases were required to adhere to the law. The government should be similarly required to enforce the law in a consistent and predictable fashion. Immigration officials should not make arbitrary decisions which are capricious in manner and application. The rules were clear and, had they been applied in a consistent, predictable way, it would be easier to say that the claimants' cases were handled in a way that is consistent with Weber's ideas of an ideal bureaucracy and formal rational law. However, insofar as this law is not uniformly and consistently applied, the law at issue here is more akin to substantive irrational law than to rational law. This classification is especially true considering the varied degrees of delays between the time of release from criminal custody and the time of immigration arrest and detention. The plaintiffs in Nielsen (2019) and Barton (2020) have all been living in the US for many years with no issues. The government was seeking to hold immigrants indefinitely while processing deportation in Nielsen (2019). The government was seeking to retroactively declare Barton inadmissible when he had been legally admitted into the U.S. in 1989 and granted permanent resident status in 1992. That inconsistency strongly indicates the need for the judiciary to consider the constitutional implications of the injustices visited upon the plaintiffs in Nielsen (2019) and Barton (2020). The majority did not visit these constitutional concerns.

One can plausibly argue that a law that is rarely enforced has much potential for abuse since it will also likely be rarely followed. Such laws are left up to the discretion of the enforcement bureaucracy to determine the actual content of the law. For example, sodomy laws were rarely enforced even before the decision in Bowers v. Hardwick (1986). Decisions to enforce the sodomy laws were often based on other considerations, such as whether the police had reason to suspect other criminal infractions but lacked probable cause to pursue them, or just did not like gay men. While the decision in Lawrence v. Texas (2003) was objectively based on equal protection, the concurring opinion of Justice $\mathrm{O}^{\prime}$ Connor made it clear that there was a meaningful worry about arbitrary action by the police.

In Nielsen (2019) and Barton (2020), the lack of any consistency in the enforcement of the criminal alien statute created a similar demand for the Court to address the constitutional issues that result when differential enforcement is the norm. Unfortunately, the majority's refusal to 
consider the constitutional issues opens the door to widely disparate and unpredictable outcomes for residents in the position of the plaintiffs. A lawyer seeking to give counsel to a non-citizen charged with a criminal offense cannot predict what will happen to their client and cannot give sound advice. A significant component of Weber's theory of rational legal form of governance is that the law should be clear and consistently applied. Not surprisingly, however, immigration law is anything but clear or consistently applied and these rulings exacerbates that problem instead of resolving it. In reality, immigration law has been characterized as a "multilayered jurisdictional patchwork" because it lacks consistent application across federal, state, county, and city levels of government (Varsanyi et al., 2012, p. 139). While the Illegal Immigration Reform and Immigrant Responsibility Act (IIRIRA) of 1996 authorized cooperation between the federal, state, county, and city governments, it is not mandatory (Varsanyi et al., 2012). As such, immigration enforcement as it is currently employed results in "an emerging, confusing, and often contradictory geography of immigration enforcement in the United States" (Varsanyi et al., 2012, p. 139).

Further proof that the Court's ruling is more akin to substantive irrational law is found in the Court's determination that the statute in question means that the criminal aliens are inherently dangerous criminals worthy of mandatory detention. If this determination is an accurate statement of legislative intent, then it stands to reason that the government would undertake due diligence to arrest them immediately upon their release. The Court's ruling in Gundy v. United States (2019) concerning 34 U.S.C. §20913(d)'s mandate that the Attorney General must apply the sex offender notification provisions as soon as feasible to offenders convicted before the statute was enacted is not consistent with giving immigration officials this kind of discretion. More importantly though, despite political arguments to the contrary, social scientific evidence indicates that immigrants commit no more crime than their U.S. born counterparts, and may commit fewer crimes (Chalfin \& Deza, 2020; Diaz, 2011; Martinez, Lee, \& Nielsen, 2006; Ousey \& Kubrin, 2014; Stansfield et al., 2013; Vélez \& Lyons, 2012). Even when they are victims of crime, immigrants, whether they are documented or undocumented, want little attention from the legal system (Bernat, 2019). This is not to say that immigrants do not commit crimes. Young, male immigrants, much like their citizen counterparts, are more likely to be involved in criminal activity than other cohorts; but immigrants also provide protective factors against crime (Chalfin \& Deza, 2020). Some scholars point out that undocumented immigrants might not be predisposed to commit crime because they wish to pursue economic stability for their families and have help surviving if they have limited economic means from their social networks. Light and Miller (2018) in their study of violent crime data from the Uniform Crime Reports and the national victimization survey found that lower crime rates among undocumented immigrants was not just a result of less reporting, but less crime commission.

\section{NIELSEN (2019) AND BARTON'S (2020) HOLDINGS NEGATIVELY IMPACT LEGITIMACY OF THE JUDICIARY}

The question still remains as to whether the Court's rulings in Nielsen (2019) and Barton (2020) will negatively impact the government's legitimacy and/or the significance of the rule of law in similar legal matters or immigration related matters. The legitimacy of a judicial system is adversely affected when it is perceived as partisan, political, or departs from the rule of law. One of the benefits of the rule of law is predictability. Vuolo (2014, p. 157) asserted that Weber's formal 
rational law "strives for predictability." Given that the Nielsen (2019) decision gives immigration officials carte blanche to enforce, or not enforce, the law and detain a person deemed to be a deportable criminal alien at any time, there is no predictability. That the Barton (2020) holding overlooks Barton's long-term continuous residency in the United States and permanent legal status, retroactively to declare him "inadmissible" challenges the very notion of accountability and predictability. These rulings negate our common understanding of the substantive content of due process in the context of immigration law.

This is especially true considering that modern theories of legitimacy are viewed and driven by a sense of procedural justice (Vuolo, 2014). As such, it is important to the legitimacy of the law and obedience thereof that authorities, legislatures, courts, and administrators alike understand that "when people perceive a decision-making process to be procedurally fair, they are likely to be satisfied with the outcome even when it does not favor them" (Jenness \& Calavita, 2018, p. 42). There can be no sense of procedural justice when immigration officials are free to seize, detain without bond, and then seek judicial clearance to deport a person without limits. One can argue that the Court's reasoning was based solely on accepted principles of statutory interpretation; however, when you cut through the layers of strict application of the law and the relative ease with which the majority refused to consider the equities in this case, the procedural unfairness in the case undermines the legitimacy of the rule of law and the government entrusted to enforce it.

The legitimacy of the judiciary is also adversely affected when the Court is perceived as acting on overtly partisan grounds, or swayed by the political exigencies of the moment. Much of President Trump's base supports his harsh immigration policies out of a sense of what Tosh (2019) called "moral panic." Specifically, moral panic leads to law that is created as an extreme form of punishment to a social problem that is sensationalized by politicians and/or the media and is accepted as true by the general public (Tosh, 2019). Unfortunately for Latin American immigrants, tremendous effort has been made to link them to the illegal drug trade and violent crime and thus this group became an easy target for harsh and punitive laws. Not surprisingly, punitive immigration policies remove a person away from family, from work, and from life in general for long periods of time in situations where guilt has not been established and where relief from removal should be available (Bosworth, 2017). Despite a conservative political belief that Hispanics, documented or undocumented, pose a threat to the public, moral panics surrounding an ethnic Hispanic threat are unfounded (Holmes et al., 2008). To the extent that the Court is perceived as relying on the Trump Administration's stated political goals in upholding the power of the state to seize and detain the plaintiffs without bond, it is perceived as acting as a political body. Given the partisan divide over this issue, the Court is acting in a way that appears partisan.

Even assuming the Court's rulings in these two cases held some iota of substantive justice, it did so at the expense of procedural justice. It is important to note that substantive justice does not always occur by religiously following the rules because an important consideration of either type of justice is fairness and reasonableness; not only as written but also as applied, something duly considered by the dissenting Justices in Nielsen (2019) and in Barton (2020).

Undoubtedly, immigration law is a very complex set of substantive and procedural rules. In 1996, IIRIRA expanded the list of crimes and criminal categories of offenses that made an alien deportable, and made application of this newly expanded list retroactive. Hence, criminal actions and convictions from years earlier made a great deal more aliens deportable years after their pleas and/or convictions. Generally, retroactive application of a law that increases criminal penalties or 
makes actions criminal that were previously noncriminal are prohibited under the U.S. Constitution's Ex Post Facto Clause (U.S. Const. art. I, §9 cl. 3 \& art. I $\S 10 \mathrm{cl}$. 1). However, this prohibition is limited to criminal laws and has no bearing on civil or administrative law (Calder $v$. Bull, 1798). The retroactive application of the law in immigration proceedings which are noncriminal in nature, undoubtedly, imposes harsh and unjust consequences on un-suspecting aliens years after the fact. In effect, the statute, as interpreted, amounts to a bill of attainder against these aliens, a status which can be enforced, or not, by the administration with no oversight by the judiciary.

Other political strains exacerbate the political stress on the legitimacy of the Court in 2020. Justice Ruth Bader Ginsburg died on September 18, 2020. President Trump quickly nominated Seventh Circuit Judge Amy Coney Barrett, a strongly conservative female judge who, if confirmed, is expected to impact the liberal-conservative balance on the Court for decades. The Republican Senate promised to move quickly to confirm Judge Barrett despite having refused to consider President Obama's nomination of Merrick Garland to replace Antonin Scalia in 2016. Meanwhile, a politically charged Presidential election between President Trump and Democratic nominee Joe Biden heightened discord between the parties. President Trump contended that the Democratic Party engaged in voter fraud in 2016 and that the 2020 election process is fraught with problems of fraud with regard to the mail-in ballot process. He stated that he expected the election to be contested and that the validity of the vote will wind up in the hands of the Court. The legitimacy of President Trump's hardened immigration policies (Meissner \& Gelatt, 2019) is tied to these larger political disputes.

The policy implications of these decisions are dire for immigrants during an administration that is opposed to immigration. At any time, for any reason, a person with a past conviction for possession of marijuana, something legal in many states now, could find themselves in detention and under imminent threat of deportation. Any offense that was committed early on in a person's residency within the nation can be raised long after a person has been conferred legal residency as a reason to deport the person. Their lawyers will not really know how to advise them. Their families will suffer with them. Their businesses will fail. Immigrant communities will learn not to trust the federal government. None of these outcomes are positive.

It is exceedingly important to acknowledge Ryo's (2017) findings that immigrant detainees' respect of the law and legal authority is also based on their perceptions of fair treatment within the system. This is true not only of their own personal encounters with the system but also of encounters seen or heard about with regard to treatment of others. What immigrants experience in the United States, while under immigration custody and while in legal proceedings, can be easily and extensively spread worldwide and bring concern about the nation's stature as an advanced governmental system. As Ryo (2017, p. 101) aptly states, "Immigrant detainees thus have the potential to widely disseminate expressions of deference and trust, or cynicism and de-legitimating beliefs about the U.S. legal system and authorities-not only within the United States, but also around the world."

At least one new immigration case has already been accepted for review in the 2020 term of the Court. ${ }^{4}$ It comes to a Court whose political neutrality is already in question (Greenhouse, 2019; Tang, 2019). The cases concerning the ability of the Trump Administration to resist oversight

${ }^{4}$ Pereida v. Barr (19-438). 
by Congress and by state district attorneys will test the Court's legitimacy once again (Brettschneider, 2019; Liptak, 2019; Totenberg, 2019). The lower courts will need to be ever so careful in how they justify their decisions in these remanded cases. Regardless of how they navigate these treacherous waters, the judiciary will be perceived as acting in a partisan way by court observers. The Court is already, according to some observers, trying to avoid controversy (Liptak, 2018), but the slate of cases scheduled for argument in the next few years will force the Court even further into the partisan political wars (Detrow, Montanaro, \& Totenberg, 2019).

This sense of unease over the impartiality of the Court is not remedied by two other recent immigration decisions, Nasrallah v. Barr (2020) and Department of Homeland Security v. University of California (2020). While both those cases resulted in rulings favoring the plaintiffs, the end result of both cases is likely not to be in their favor. Nasrallah's convention Against Torture claim was denied on remand (Nasrallah v. United States AG 2020). In the case involving the Deferred Action for Childhood Arrivals (DACA) program, the upshot is that the Trump Administration merely has to go back and start the rulemaking process all over again. The Court made it clear that the Trump Administration had the power to engage in rulemaking to end this program; the administration's process just has to have an appearance that it is not arbitrary and capricious. A third recent ruling further reinforces our argument that the Court is not interested in considering the due process rights of immigrants. In Department of Homeland Security v. Thuraissigiam (2020), the Court refused to allow an undocumented immigrant's asylum claim to be heard via a habeas corpus petition. Vijayakumar Thuraissigiam had sought to vacate an immigration court's removal order after an expedited removal proceeding.

\section{CONCLUSION}

Under a model view of the judiciary in a democracy as derived from Weber's theories of formal rational law and a legal rational society, the judiciary functions in a nonpartisan, apolitical fashion to preserve the rule of law in the society. Those caught up in the judicial system are able to discern what the law is, why the law is as it is, and to make reasonable predictions regarding the outcome of their case. Additionally, the outcomes are not only accepted as legitimate because of the consistency of the process, but the substantive outcomes are generally perceived to be equitable as well.

Under these criteria, the decisions in Nielsen v. Preap (2019) and Barton v. Barr (2020) are fatally flawed. Not only is there a plausible argument that the Court did not act in a politically neutral, non-partisan way, but the resulting law after these decisions allows for arbitrary and capricious actions by immigration officials. While a certain amount of discretion in inevitable in enforcing the criminal law, it is the role of the courts to police that discretion to ensure that it stays within the bounds of the Constitution. Here, the boundaries of that discretion are without limit or judicial oversight. Lawyers providing counsel to clients facing removal from the country cannot tell the client whether they will be detained and deported with any certainty (Immigration Defense Project \& National Immigration Project of the National Lawyers Guild, 2020). What is worse, some of those who are eligible to be detained will be released from custody and live out a productive life for years or even decades only to fall prey to an immigration official when he or she comes to their attention for some reason unrelated to their earlier removal offenses. The Court's holdings produce results that are patently unfair. What is a person expected to think when their neighbor of eleven years, with whom they have been friends and colleagues, suddenly disappears? What 
Journal of Criminal Justice and Law: Official Journal of the Law and Public Policy Section of the Academy of Criminal Justice Sciences

are legal permanent residents supposed to think when their residency and legal status is challenged many years after they have established themselves with jobs, homes and families in the United States? These decisions may be the kind of outcomes one expects in totalitarian societies, not in a society governed by the rule of law.

The substantive outcomes are also inequitable because of the severity of the punishment. For people who have lived in this country since they were children, deportation puts them into a society with which they have no connections. They may not speak the language and may know not a single soul in their new home. For those who have come to this country as refugees, there is no more severe punishment than being deported and sent back to a country abandoned for fear of extreme poverty, persecution, violence, or even death. For persons who are long time permanent legal residents, the substantive justice concerns are troubling.

When the judiciary does not check the actions of an executive branch that fails to follow the rule of law, it becomes a party to the resulting injustice. When citizens perceive that unfair outcomes are common, the judiciary loses legitimacy. Our judiciary makes us the envy of the world, but the rulings in Nielsen v. Preap (2019) and Barton v. Barr (2020) harm the judiciary and should be reconsidered.

\section{Declaration of Conflicting Interests}

The author declares no potential conflicts of interest with respect to the research, authorship, and/or publication of this article.

\section{Funding}

The author received no financial support with respect to the research, authorship, and/or publication of this article.

\section{Sources Cited}

\section{Constitution}

U.S. Const. art. I, $\$ 9 \mathrm{cl} .3$.

U.S. Const. art. I, $\S 10 \mathrm{cl} .1$.

\section{Federal Law}

Illegal Immigration Reform and Immigrant Responsibility Act of 1996, Title 8 U.S.C. ch. 12.

Immigration and Nationality Act of 1952, Title 8 U.S.C. $\S \S 1226-1227$.

\section{Cases}

Barton v. Barr, 590 U.S. __, 140 S. Ct. 1442 (2020).

Barton v. U.S. Attorney General, 904 F.3d 1294 (11th Cir., 2018).

Bowers v. Hardwick, 478 U.S. 186, 106 S. Ct. 2841 (1986).

Calder v. Bull, 3 U.S. 386 (1798).

Department of Homeland Security v. Regents of the University of California, 591 US , 140 S. Ct. 1891 (2020).

Department of Homeland Security v. Thuraissigiam, 591 U.S. 140 S. Ct. 1959 (2020). 136 S. Ct. 2198 (2016). 
Flowers v. Mississippi, 588 U.S. 139 S. Ct. 2228 (2019).

Gundy v. United States, 588 U.S. __, 139 S. Ct. 2116 (2019).

Lawrence v. Texas, 539 U.S. 558, 123 S. Ct. 2472 (2003).

League of Women Voters of Pennsylvania et al., v. Commonwealth of Pennsylvania et al., 644 Pa. 287 (2018).

Nasrallah v. Barr, 590 U.S. __, 140 S. Ct. 1683 (2020).

Nasrallah v. United States AG, 2020 U.S. App. LEXIS 24962 (11th Cir., 2020).

Nielsen v. Preap, 568 U.S. _, 139 S. Ct. 954 (2019).

Nielsen v. Preap (2019) Oral Argument, October 10, 2018.

Preap v. Johnson, 831 F.3d 1193 (9th Cir., 2016).

Riley v. California, 573 U.S. 373, 134 S. Ct. 2473 (2014).

Roe v. Wade, 410 U.S. 113, 93 S. Ct. 705 (1973).

Trump v. Hawaii, 585 U.S. 138 S. Ct. 2392 (2018).

Trump v. Mazars, USA, 591 U.S. __, 140 S. Ct. 2019 (2020).

Trump v. Vance, 591 U.S. __, 140 S. Ct. 2412 (2020).

United States v. Jones, 565 U.S. 400, 132 S. Ct. 945 (2012).

United States v. Montalvo-Murillo, 495 U.S. 711, 110 S. Ct. 2072 (1990).

\section{Articles}

Ackerman, B. (2002). Bush vs. Gore: The question of legitimacy. New Haven, CT: Yale University Press.

Bartels, B. L., \& Johnson, C. D. (2013). On the ideological foundations of Supreme Court legitimacy in the American public. American Journal of Political Science, 57(1), 184-199.

Bernat, F. (2019). Immigration and crime. In Henry Pontell, (Ed.). Oxford Research Encyclopedia of Criminology and Criminal Justice. Oxford, UK: Oxford University Press.

Bosworth, M. (2017). Immigration detention, punishment and the transformation of justice. Social \& Legal Studies, 28(1), 81-99.

Brettschneider, C. (2019, November 15). The Supreme Court should tell Trump he is not above the law. New York Times.

Chaflin, A. \& Deza, M. (2020). Immigration enforcement, crime, and demography: Evidence from the Legal Arizona Workers Act. Crime \& Public Policy, 19(2), 515-562.

Chen, A. H. Y. (1999). Rational law, economic development and the case of China. Social \& Legal Studies, 8(1), 97-120.

Collins, S. (2018, October 15). Read Susan Collins's speech declaring support for Brett Kavanaugh. New York Times.

Detrow, S., Montanaro, D., \& Totenberg, N. (2019, October 7). Abortion, guns and LGBTQ rights on the docket for Supreme Court's new term. NPR Podcast.

Diaz Jr., J. (2011). Immigration policy, criminalization and the growth of the immigration Industrial complex: Restitution, expulsion, and eradication of the undocumented in the U.S. Western Criminology Review, 12(2), 35-54.

Farmer, J. F. (2013) Max Weber's sociology of law applied to a case of judicial intervention into state-sanctioned inmate abuse. Journal of Sociological Research, 4(2), 147-166.

Flegenheimer, M., Liptak, A., Hulse, C., \& Savage, C. (2017, March 21). Seven highlights from the Gorsuch confirmation hearings. New York Times. 
Journal of Criminal Justice and Law: Official Journal of the Law and Public Policy Section of the Academy of Criminal Justice Sciences

Golde, K. (2019, October 22). Recent polls show confidence in Supreme Court, with caveats. Scotusblog.

Greenhouse, L. (2019, November 21). Can the Supreme Court save itself? Two cases threaten to reinforce its image as a political captive of the Trump administration. New York Times.

Holmes, M. D., Smith, B. W., Freng, A. B., \& Muñoz, E. A. (2008) Minority threat, crime control, and police resource allocation in the southwestern United States. Crime \& Delinquency, 54(1), 128152.

Immigration Defense Project \& National Immigration Project of the National Lawyers Guild (2020, May 5). Practice alert: The impact of Barton v. Barr on eligibility for cancellation of removal.

Jenness, V., \& Calavita, K. (2018). "It depends on the outcome": Prisoners, grievances, and perceptions of justice. Law \& Society Review, 52(1), 41-72.

Joosse, P. (2018). Countering Trump: Toward a theory of charismatic counter-roles. Social Forces, 97(2): 921-944.

Keneally, M. (2020, February 5). Trump Impeachment: Here is How the Process Works. ABC News.

Lane, J. E. (2017). Max Weber's theory of civilizations today: The rule of law instead of capitalism. Arts and Humanities Open Access Journal, 1(1), 4-9.

Lasser, M. D. S. (2009). Judicial deliberations: A comparative analysis of judicial transparency and legitimacy. Oxford, U.K.: Oxford University Press.

Light, M. T., \& Miller, T. (2018). Does undocumented immigration increase violent crime? Criminology, 56(2), 370-401.

Lipset, S. M. (1959). Some social requisites of democracy: Economic development and political legitimacy. American Political Science Review, 53(1), 69-105.

Liptak, A., Stolberg, S. G., Savage, C., \& Shear, M. D. (2018, September 5). Day 2 of the Kavanaugh confirmation hearings: Leahy brings up Bush-era scandal. New York Times.

Liptak, A. (2019, December 5). Trump again asks Supreme Court to bar release of his financial records. New York Times.

Liptak, A. (2018, December 23). John Roberts, leader of Supreme Court's conservative majority, fights perception that it is partisan. New York Times.

Marquez, X. (2016). The irrelevance of legitimacy. Political Studies, 64, 19-34.

Martinez Jr., R., Lee, M. T., \& Nielsen, A. L. (2006). Segmented assimilation, local context and determinants of drug violence in Miami and San Diego: Does ethnicity and immigration matter? International Migration Review, 38(1), 131-157.

Meissner, D., \& Gelatt, J. (May 2019). Eight key U.S. immigration policy issues: State of play and unanswered questions. Migration Policy Institute.

Novak, M. (2013). Ideal types of law from the perspective of psychological typology. Journal for Constitutional Theory and Philosophy of Law, 19, 205-232.

Ousey, G. C., \& Kubrin, C. E. (2014). Immigration and the changing nature of homicide in US cities, 1980-2010. Journal of Quantitative Criminology, 30, 453-483.

Pedrioli, C. A. (2016). Judicial neutrality awash with ideology: Justice Scalia, sexual orientation, and rhetorical personae. Texas Journal on Civil Liberties \& Civil Rights, 21(2), 183-217.

Roberts, J. G., Jr. (2019, December 31). 2019 year-end report on the federal judiciary.

Ryo, E. (2017). Legal attitudes of immigrant detainees. Law \& Society Review, 51(1), 99-131.

Sabuktay, A. (2009). Locating extra-legal activities of the modern state in legal-political theory: Weber, Habermas, Kelsen, Schmitt and Turk. Crime, Law \& Social Change, 51, 511-530. 
Sahni, I. P. (2009). Max Weber's sociology of law. Journal of Classical Sociology, 9(2), 209-233.

Schaff, L. A. (2014). Weber and the Weberians. New York: Palgrave McMillan.

Schaff, L. A. (2011). Max Weber in America. Princeton, NJ: Princeton University Press.

Segal, J. A. \& Spaeth, H. J. (2002). The Supreme Court and the Attitudinal Model revisited. New York: Cambridge University Press.

Stansfield, R., Akins, S., Rumbaut, R. G., \& Hammer, R. B. (2013). Assessing the effects of recent immigration on serious property crime in Austin, Texas. Sociological Perspectives, 56(4), 647672.

Stevens, M. (2020, February 8). Trump has reshaped the judiciary. Here's how the 2020 Democrats would address that. New York Times.

Tang, A. (2019, November 26). Conservative hypocrisy makes its case at the Supreme Court: Lawyers on the right are advancing arguments they once rejected on principle. New York Times.

Tosh, S. (2019). Drugs, crime, and aggravated felony deportations: Moral panic theory and the legal construction of the "criminal alien." Critical Criminology, 27, 329-345.

Totenberg, N. (2019, October 24). A look at the court cases where the Trump administration is fighting subpoenas. All Things Considered.

Totenberg, N. (2018, August 7). Is Trump about to be able to say "you're fired" to a lot more people? National Public Radio, Morning Edition.

U.S. Immigration and Customs Enforcement. (2019). U.S. Immigration and Customs Enforcement fiscal year 2019 enforcement and removal operations report: Enforcement and removal operations.

Varsanyi, M. W., Lewis, P. G., Provine, D. M., \& Decker, S. (2012). A multilayered jurisdictional patchwork: Immigration federalism in the United States. Law \& Policy, 34(2), 138-158.

Vélez, M. A. \& Lyons, C. J. (2012). Situating the immigration and neighborhood crime relationship across multiple cities. In Charles E. Kubrin, M. S. Zatz, \& R. M., Punishing immigrants: Policy, politics, and injustice (pp. 159-177). New York: NYU Press.

Vuolo, M. (2014). Incorporating consensus and conflict into the legitimacy of law. Crime, Law \& Social Change, 62, 155-170.

Weber, M. (1946). From Max Weber: Essays in sociology. Trans. H. H. Gerth and C. Wright Mills. New York: Oxford University Press.

Weber, M. (1958). The three types of legitimate rule. Berkeley Publications in Society and Institutions, 4(1), 1-11. Translated by Hans Gerth.

Weber, M. (1966). Max Weber on law in economy and society (2nd printing). Trans. Max Rheinstein. Cambridge, MA: Harvard University Press.

Weber, M. (1968). Max Weber on charisma and institution building. Ed. by S. N. Eisenstadt. Chicago: University of Chicago Press.

Weber, M. (1983). Max Weber on capitalism, bureaucracy and religion: A selection of texts. Trans. Stanislav Andreski. London: George Alen \& Unwin.

Wehle, K. (2020, February 4). Congress has lost its power over Trump. The Atlantic. 